\title{
Vitamin D Receptor Expression in Lumbar Disc Degeneration Patients
}

\author{
Mahmoud M. Taha ${ }^{1}$, Norhan A. Sabbah ${ }^{2}$, Noha A. Rezk ${ }^{2}$, Hosam Mansour ${ }^{3}$ \\ ${ }^{1}$ Neurosurgery Department, Faculty of Medicine, Zagazig University, Zagazig, Egypt \\ ${ }^{2}$ Medical Biochemistry Department, Faculty of Medicine, Zagazig University, Zagazig, Egypt \\ ${ }^{3}$ Radiology Department, Faculty of Medicine, Zagazig University, Zagazig, Egypt \\ Email: *mahmoudlotfy1972@yahoo.co.uk
}

How to cite this paper: Taha, M.M., Sabbah, N.A., Rezk, N.A. and Mansour, H. (2017) Vitamin D Receptor Expression in Lumbar Disc Degeneration Patients. Open Journal of Modern Neurosurgery, 7, 19-33. https://doi.org/10.4236/ojmn.2017.72003

Received: January 27, 2017

Accepted: April 10, 2017

Published: April 13, 2017

Copyright (c) 2017 by authors and Scientific Research Publishing Inc. This work is licensed under the Creative Commons Attribution International License (CC BY 4.0).

http://creativecommons.org/licenses/by/4.0/

\section{c) (i) Open Access}

\begin{abstract}
Background: Lumbar disc degeneration [LDD] is the main cause of low back pain, and is a medical circumstance that poses a great load on the global health care system with serious socioeconomic consequences. The aim of this study was to determine the association of vitamin $\mathrm{D}$ receptors (VDR) gene Fok1 polymorphism, VDR expression and vitamin D level with LDD susceptibility and severity in Egyptians. Materials and methods: A total of unrelated 169 female patients with low back pain diagnosed as having lumbar disc degeneration and 169 controls were enrolled in the study. VDR Fok1 polymorphism was determined using restriction fragment length polymorphism-polymerase chain reaction [PCR-RFLP]. VDR expression was measured by reverse transcriptase PCR, while, serum levels of vitamin $\mathrm{D}$ were measured by high performance liquid chromatography [HPLC]. Results: Subjects with VDR Fok1 ff genotype were significantly more likely to develop LDD in Egyptians and associated with multilevel disc degeneration and disc herniation (adjusted $\mathrm{OR}=7.9,95 \% \mathrm{CI}=2.3-26.6$ and $P=0.01$ ) and (adjusted $\mathrm{OR}=2.2$, 95\% CI $=1.6-3.7$ and $P=0.031)$ respectively. VDR expression and vitamin $\mathrm{D}$ levels were significantly decreased in LDD patients and with multilevel disc degeneration and herniation, (adjusted $P=0.042$ and adjusted $P=0.028$ ) respectively. Conclusion: VDR Fok1 mutant alleles and genotypes are associated with the development and severity of LDD in Egyptians. Also, VDR expression and vitamin $\mathrm{D}$ level could be the marker for monitoring LDD.
\end{abstract}

\section{Keywords}

Lumbar Disc, Vitamin D, Degeneration, Polymorphism, PCR

\section{Introduction}

Lumbar disc degeneration (LDD) is the fundamental driver of low back pain, 
and is a therapeutic condition that represents an incredible burden on the worldwide human services framework with genuine financial outcomes [1]. Degenerated discs happen in $40 \%$ of people under 30 years old and more prominent than $90 \%$ of those more than 50 [2]. The risk factors for LDD incorporate family history, lumbar load and work stack, so the occurrence of LDD is much more in developing states, particularly in Egypt [3].

The etiology of DD was only ascribed to the buildup of environmental factors, injury, and way of life, smoking, atherosclerosis, and disc degeneration with aging [4]. Nevertheless, recent researches have shown that the impact of these components is moderate in $\mathrm{DD}$, fortifying the conviction of hereditary contribution in the causes of the ailment [5] [6].

Furthermore, lumbar degeneration does not invariably go to painful conditions, making painful degeneration a difficult and subjective topic to read and motivating more precise definitions of degeneration [7].

Vitamin D is considered as a hormone that is responsible for calcium homeostasis and bone mineralization [8]. Vitamin D biological activities are regulated by a high-affinity receptor that works as a transcription factor activated by ligands.

Vitamin D receptor (VDR) gene is the first reported gene possibly connected with LDD risks [9]. It is found on human chromosome 12 [12q12-q14]; its length is $100 \mathrm{~kb}$, with more than 100 restriction cutting sites [10]. VDR is one of the steroid superfamiles of nuclear receptor, which mostly manages the transcriptional activity of 1,25-dihydroxyvitamin D3 [active metabolite of vitamin D] [11]. The VDR FokI polymorphism is an autonomous polymorphic site situated in exon 2 and prompts an alternate translation initiation site, prompting the development of a longer VDR isoform, expected to be less active [12] [13].

Previous studies examined the relationship of polymorphisms in VDR gene Fok1 polymorphism with LDD [14] [15] [16]. However, their data are conflicting; therefore, further studies in different populations are essentials.

On the foundation of this consideration, we proposed to investigate whether VDR Fok1 polymorphism, VDR expression and vitamin D level contributed to LDD susceptibility and severity of in Egyptians.

\section{Subjects and Methods}

\subsection{Subjects}

A total of unrelated 169 female patients (mean age $42.3 \pm 11.56$ years) with low back pain diagnosed as having lumbar disc degeneration (LDD) were recruited from the follow-up and inpatient units of Neurosurgery Department, Zagazig University Hospitals, Egypt between January, 2014 and December 2015.

Patients with LDD were firstly suspected by their history of low back pain and/or sciatic pain. Then, the diagnosis was established according to the reports of Radiology department and the approval of the neurosurgeon (Taha MM), the MRI of lumbosacral spine of the patients showed degenerated lumbar disc.

Exclusion criteria: Subjects with autoimmune, inflammatory diseases, hyper- 
tension, diabetes, previous surgical procedures in the lumbar spine, severe osteoporosis, segmental instability, those with no LDD in MRI or those with pathologies other than LDD.

Clinical and demographic characteristics of LDD patients are summarized in Table 1.

The control group included one hundred and sixty nine healthy females (mean age $28.4 \pm 10.38$ years) with no medical history of low back pain (LBP) or LDD. They were healthy volunteers recruited from females visited outpatients' clinics for regular medical examination, nurses in the same hospitals. They were ethnic origin and socioeconomic status matched with the patients.

Data regarding individual characteristics were collected by a questionnaire that included items on anthropometric measures. The body mass index (BMI = weight in $\mathrm{Kg}$ per height in meters squared) was calculated for each subject. Smoking habits, family history of lumbar disc disease and past history of back injury were recorded. A separate questionnaire, prepared by the Stockholm Musculoskeletal Intervention Center for assessing manual materials handling, was altered and enforced to the assessment of physical loads by (Wiktorin et al., 1996) [17]. Subjects were asked to recall in details their employment history, including descriptions of past occupations. Heavy physical load was defined as $\leq 4$ $\mathrm{h} /$ day for $>5$ years or $>4 \mathrm{~h} /$ day for $>2.5$ years [17].

Magnetic resonance imaging scans (with a slice thickness of $5 \mathrm{~mm}$, a repetition of $2500 \mathrm{msec}$, and an echo time of $90 \mathrm{msec}$ ) of the lumbar spine was performed with the use of a 1.5-T Magnetom unit (Achieva, Philips Healthcare, Best, Netherland) for both patients and control groups. The scans were independently assessed by 2 observers. The grade of disc degeneration was determined according to the four-grade classification system described by (Pfirrmann et al. 2001) [18].

Grade 1 (normal) indicated normal signal height and intensity; grade 2 (intermediate), a speckled pattern or heterogeneous decreased signal intensity; gra-

Table 1. Clinical and demographic characteristics of the studied subjects.

\begin{tabular}{cccc}
\hline & $\begin{array}{c}\text { Control group } \\
(\mathrm{N}=169)\end{array}$ & $\begin{array}{c}\text { LDD group } \\
(\mathrm{N}=169)\end{array}$ & P value \\
\hline Age years $($ mean $\pm \mathrm{SD})$ & $28.4 \pm 10.38$ & $42.3 \pm 11.56$ & $<0.001^{*}$ \\
$\begin{array}{c}\text { Body mass index }\left(\mathrm{kg} / \mathrm{m}^{2}\right) \\
\text { mean } \pm \mathrm{SD}\end{array}$ & $24.8 \pm 4.2$ & $25.0 \pm 3.1$ & 0.6 \\
+ ve Family history $n(\%)$ & $50(29.5)$ & $77(45.5)$ & $0.003^{*}$ \\
Smoking history $n(\%)$ & $52(30.7)$ & $68(40.2)$ & 0.07 \\
Back injury $n(\%)$ & $27(15.9)$ & $55(32.5)$ & $0.006^{*}$ \\
Exercise $n(\%)$ & $98(57.6)$ & $57(33.7)$ & $0.001^{*}$ \\
Heavy physical load $n(\%)$ & $39(23)$ & $61(36.1)$ & $0.01^{*}$ \\
\hline
\end{tabular}

Quantitative data were presented as mean \pm standard deviation; qualitative data were presented as numbers and percentages. ${ }^{\star}$ Significant $(\mathrm{P}<0.05)$. 
grade of the disc degeneration was determined when the evaluation of the disc degeneration was agreed upon by at least two observers. The presence of disc herniation was also evaluated, and it was judged to be present when the two observers (Taha MM, Mansour H) agreed.

This study was approved by the ethical committee of Zagazig University and a written informed consent was obtained from all subjects before their participation in this work.

\subsection{Blood Sampling}

$5 \mathrm{ml}$ blood sample were taken from all subjects, $2 \mathrm{ml}$ into tubes containing EDTA, for genomic DNA extraction. The remaining part were left for clotting, then centrifuged and the serum were stored at $-20^{\circ} \mathrm{C}$ until analysis.

\subsection{Genomic DNA Extraction}

Genomic DNA was extracted from whole blood samples using the spin column method according to the protocol (QIAamp Blood Kit; Qiagen GmbH, Hilden, Germany). DNA was stored at $-20^{\circ} \mathrm{C}$ till the time of usage.

\subsection{Amplification of VDR Fok1 Gene Polymorphism}

The genotyping of VDR Fok1 was performed using polymerase chain reactionrestriction fragment length polymorphism (PCR-RFLP) technique as described by (Horst-Sikorska et al. 2007) [19] using forward primer 5'-AGCTGGCCCTGG CACTGACTCTGCTCT-3' and reverse primer 5'ATGGAAACACCTTGCTTCTTC TCCCTC-3'.

"Amplification was performed using a PTC-100 thermal cycler (MJ Research, Inc., Watertown, Massachusetts, USA) according to the following protocol; the initial denaturation at $95^{\circ} \mathrm{C}$ for $5 \mathrm{~min}$, followed by 35 cycles of denaturation at $95^{\circ} \mathrm{C}$ for $30 \mathrm{~s}$, annealing for $60 \mathrm{sec}$ at $60^{\circ} \mathrm{C}$ for, and extension at $72^{\circ} \mathrm{C}$ for $30 \mathrm{~s}$, followed by a final extension step at $72^{\circ} \mathrm{C}$ for $5 \mathrm{~min}$ ".

PCR product was digested by $5 \mathrm{U}$ Fok I restriction enzyme (New England Biolabs, Beverly, MA, USA) for 15 minutes at $65^{\circ} \mathrm{C}$ digested $\mathrm{f}$ allele into 69 and 196 $\mathrm{bp}$ fragments and yielded a single $265 \mathrm{bp}$ band for $\mathrm{F}$ allele. The amplified products were separated by electrophoresis on a $2 \%$ agarose gel stained with ethidium bromide and visualized under a UV transilluminator.

\subsection{Real Time-PCR Quantification for VDR Expression}

Total RNA was isolated from EDTA whole blood sample according to the manufacturer's instructions (GenElute ${ }^{\mathrm{Tm}}$ Mammalian Total RNA Miniprep Kit, sigma-Aldrich, USA).

One microgram of total RNA was reverse transcribed using Roche Transcriptorc DNA synthesis kit, according to the instructions of the manufacturer (Roche Diagnostics, Almere, Netherlands) at $50^{\circ} \mathrm{C}$ for $30 \mathrm{~min}$. Quantitative real-time was performed using SYBR green qRT-PCR assay using mi Script SYBR Green PCR kit (Qiagen, Hilden, Germany) on ABI PRISM 7500 Fast real-time PCR 
system (Applied Biosystems, Foster City, CA). "Forward and reverse primers for VDR were 5'-CTTCCCTGCCTGACCCTGGAGACTTT3-3' and 5'GCTTCAT-G-CTTCGCCTGAAGAAGCCTTTG3', for B actin 5'-TCACCCACACTGTGCCCATCTACGA-3' and 5'-CAGCGGAACCGCTCATTGCCAATGG3' respecttively". All reagents and primers were obtained from Applied Biosystems (Applied Biosystems, Foster City, CA).

"PCR amplification protocol was: denaturation at $95^{\circ} \mathrm{C}$ for $10 \mathrm{~min}$ followed by 40 cycles of denaturation at $94^{\circ} \mathrm{C}$ for $15 \mathrm{sec}$, annealing at $60^{\circ} \mathrm{C}$ for $30 \mathrm{sec}$ and extension at $72^{\circ} \mathrm{C}$ for $30 \mathrm{sec}$. Final extension was carried out at $72^{\circ} \mathrm{C}$ for $10 \mathrm{~min}$ " [20].

We took the average value of the control group as internal control. Gene expression levels were calculated and determined using the threshold cycle (CT) method (2- $\Delta \Delta \mathrm{CT}$ method).

\subsection{Measurement of Serum 25-Hydroxy Vitamin D by HPLC}

Measurement of the serum level of 25-hydroxyvitamin D is the most useful parameter in evaluating vitamin D status [21]. Quantitative HPLC assays have been done based on ultraviolet detection and normal-phase separation [22] by using (25-OH-Vitamin D3/D2 by HPLC Reagent Kit) lot no. 195-6529 by BioRad.

"Serum levels of $25(\mathrm{OH}) \mathrm{D}_{3}$ were measured by High Performance Liquid Chromatography (Perkin Elmer model LC 1020 plus), carried out on a gradient pump (Binary LC pump 250) LC 18 column (particle size $5 \mu \mathrm{m}, 250 \mathrm{~mm} \times 4 \mathrm{~mm}$ inner diameter, Supelco Inc., Supelco Park, Bellefonte, PA USA). The mobile phase was $760 \mathrm{ml} / \mathrm{L}$ methanol in water, and the flow rate was $1 \mathrm{ml} / \mathrm{min}$, the injected volume was $50 \mu \mathrm{l}$ and the ultraviolet-visible (UV-VIS) detection was at $265 \mathrm{~nm}$ ".

Calculation of the results was done through calibration curve obtained by plotting the absorbance readings of the standards against the corresponding standard concentrations and then the concentrations of the samples were read directly from the standard curve.

\subsection{Statistical Analysis}

The data were processed by SPSS (SPSS Inc., Chicago, IL, Version 11, USA) statistical package. Quantitative data were presented as mean \pm standard deviation; significant differences between the different studied groups were determined using Student's t test and one-way analysis of variance (ANOVA) test. Qualitative variables were presented as number and percentage. Differences of the frequencies in the studied groups were analyzed using chi square $\left(\chi^{2}\right)$ test. A difference was considered significant at $p$ value $<0.05$. [23] was used to estimate the statistical power of the results concerning Fok1 polymorphism data and showed power of at least $90.1 \%$ to detect the genetic effects regarding the association with LDD for the allele frequencies and sample size in the present study. 


\section{Results}

\subsection{Relation of Vitamin D Receptor Fok1 Gene Polymorphism, Expression and Vitamin D Levels with Lumbar Disc Degeneration}

The genotype frequencies of VDR Fok1 gene polymorphism were all in accordance with the Hardy-Weinberg equilibrium in all groups. We observed significant increase of VDR Foklff genotype and $\mathrm{f}$ allele frequencies in LDD patients compared to control group. Subjects with ff genotype and f allele carriers' were significantly more likely to have LDD (adjusted OR $=7.9,95 \% \mathrm{CI}=2.3-26.6$ and $\mathrm{P}=0.01$ ) and (adjusted $\mathrm{OR}=2.2,95 \% \mathrm{CI}=1.6-3.7$ and $\mathrm{P}=0.031$ ) respectively. VDR mRNA and vitamin D levels were significantly decreased in LDD patients compared to controls (adjusted $\mathrm{P}=0.009$ and adjusted $\mathrm{P}=0.003$ ) respectively (Table 2).

\subsection{Relation of Vitamin D Receptor Fok1 Gene Polymorphism, Expression and Vitamin D Levels with the Number of Levels of Disc Degeneration in LDD Patients}

The frequencies of VDR Fok1 ff genotype and $\mathrm{f}$ allele were significantly more frequently associated with multilevel disc degeneration (adjusted $\mathrm{P}=0.01$ and $\mathrm{P}$ $=0.005$ respectively). VDR mRNA and vitamin D levels were significantly decreased with the numbers of levels of disc degeneration in LDD group (adjusted $\mathrm{P}=0.042$ and adjusted $\mathrm{P}=0.028$ ) respectively (Table 3 ).

Table 2. Vitamin D Receptor Fok1 Gene polymorphism, expression and vitamin D levels in lumbar disc degeneration patients.

\begin{tabular}{|c|c|c|c|c|c|c|c|}
\hline \multicolumn{2}{|c|}{ Genotypes/alleles } & $\begin{array}{l}\text { Healthy Controls ( } n \\
=169) n(\%)\end{array}$ & $\begin{array}{l}\text { LDD patients } \\
(n=169) n(\%)\end{array}$ & OR (95\% CI) & $\mathrm{P}$ & $\begin{array}{c}\text { Adjusted } \\
\text { OR }(95 \% \text { CI })\end{array}$ & $\begin{array}{l}\text { Adjusted } \mathrm{p} \\
\text { value }\end{array}$ \\
\hline \multirow{11}{*}{$\begin{array}{l}\text { VDR } \\
\text { Fok1 }\end{array}$} & FF & $121(71.6)$ & $95(56.2)$ & & & & \\
\hline & $\mathrm{Ff}$ & $45(26.6)$ & $55(32.5)$ & $1.53(0.98-2.80)$ & 0.15 & $1.32(0.67-2.64)$ & 0.32 \\
\hline & $\mathrm{ff}$ & $3(1.8)$ & $19(11.3)$ & $8.7(2.5-29.9)$ & $0.003^{*}$ & $7.9(2.3-26.6)$ & $0.01^{*}$ \\
\hline & \multicolumn{7}{|l|}{$\begin{array}{l}\text { Dominant } \\
\text { model }\end{array}$} \\
\hline & $\mathrm{FF}+\mathrm{Ff}$ & $166(98.2)$ & $150(88.7)$ & & & & \\
\hline & $\mathrm{ff}$ & $3(1.8)$ & $19(11.3)$ & $6.0(1.3-28)$ & $0.018^{\star}$ & $5.8(1.2-26.4)$ & $0.023^{*}$ \\
\hline & \multicolumn{7}{|l|}{$\begin{array}{l}\text { Recessive } \\
\text { model }\end{array}$} \\
\hline & $\mathrm{FF}$ & $121(71.6)$ & $95(56.2)$ & & & & \\
\hline & $\mathrm{Ff}+\mathrm{ff}$ & $48(28.4)$ & $74(43.8)$ & $2.0(1.1-3.6)$ & $0.027^{*}$ & $2.4(1.0-3.5)$ & $0.033^{*}$ \\
\hline & $\mathrm{F}$ allele & $287(84.9)$ & $245(72.5)$ & & & & \\
\hline & $\mathrm{f}$ allele & $51(15.1)$ & $93(27.5)$ & $2.3(1.54-3.21)$ & $0.023^{*}$ & $2.2(1.6-3.7)$ & $0.031^{*}$ \\
\hline \multicolumn{2}{|c|}{$\begin{array}{l}\text { Vitamin } \mathrm{D}(\mathrm{ng} / \mathrm{ml}) \\
\quad(\text { mean } \pm \mathrm{SD})\end{array}$} & $36 \pm 7.1$ & $21.6 \pm 5.3$ & & $<0.001^{*}$ & & $0.003^{*}$ \\
\hline \multicolumn{2}{|c|}{$\begin{array}{l}\text { VDR mRNA level } \\
(\text { mean } \pm \text { SD) }\end{array}$} & $3.63 \pm 0.61$ & $2.98 \pm 0.8$ & & $0.007^{*}$ & & $0.009^{*}$ \\
\hline
\end{tabular}

VDR; vitamin D receptor, LDD; lumbar disc degeneration Adjusted OR: multivariate analysis; OR adjusted for age, family history, exercise, back injury and heavy physical load ${ }^{\star} \mathrm{P}<0.05$ when compared to control group. 
Table 3. VDR Fok1 gene polymorphism, expression and vitamin D levels as regards the number of levels of disc degeneration in LDD patients.

\begin{tabular}{|c|c|c|c|c|c|c|}
\hline \multirow[t]{2}{*}{ Genotypes } & \multicolumn{4}{|c|}{ Levels with disc degeneration } & \multirow[b]{2}{*}{$\mathrm{P}$} & \multirow[b]{2}{*}{$\begin{array}{c}\text { Adjusted } \\
\text { p value }\end{array}$} \\
\hline & $\begin{array}{c}0(n=58) \\
n(\%)\end{array}$ & $\begin{array}{c}1(n=47) \\
n(\%)\end{array}$ & $\begin{array}{c}2(n=31) \\
n(\%)\end{array}$ & $\begin{array}{c}\geq 3(n=33) \\
n(\%)\end{array}$ & & \\
\hline FF & $48(82.7)$ & $30(63.8)$ & $10(32.2)$ & $7(21.2)$ & & \\
\hline $\mathrm{Ff}$ & $9(15.5)$ & $13(27.7)$ & $15(48.4)$ & $18(54.5)$ & $0.002^{*}$ & $0.01^{*}$ \\
\hline ff & $1(1.8)$ & $4(8.5)$ & $6(19.4)$ & $8(24.3)$ & & \\
\hline \multicolumn{7}{|c|}{ Dominant model } \\
\hline $\mathrm{FF}+\mathrm{Ff}$ & $57(98.2)$ & $43(91.5)$ & $25(80.6)$ & $25(75.7)$ & & \\
\hline $\begin{array}{l}\text { VDR } \\
\text { Fok1 }\end{array}$ & $1(1.8)$ & $4(8.5)$ & $6(19.4)$ & $8(24.3)$ & $<0.001^{*}$ & $0.004^{*}$ \\
\hline \multicolumn{7}{|c|}{ Recessive model } \\
\hline $\mathrm{FF}$ & $48(82.7)$ & $30(63.8)$ & $10(32.2)$ & $7(21.2)$ & & \\
\hline $\mathrm{Ff}+\mathrm{ff}$ & $10(17.3)$ & $17(36.2)$ & $23(67.8)$ & $26(78.8)$ & $<0.001^{*}$ & $0.006^{*}$ \\
\hline F allele & $105(90.5)$ & $73(77.6)$ & $35(56.4)$ & $32(48.4)$ & & \\
\hline f allele & $11(9.5)$ & $21(22.4)$ & $27(43.6)$ & $34(51.5)$ & $0.001^{*}$ & $0.005^{*}$ \\
\hline $\begin{array}{l}\text { Vit D }(\mathrm{ng} / \mathrm{ml}) \\
(\text { mean } \pm \mathrm{SD})\end{array}$ & $25.4 \pm 4.2$ & $22.3 \pm 5.6$ & $20.3 \pm 5.8$ & $19.5 \pm 4.9$ & $\begin{array}{c}0.024^{*} \\
(\text { mean } \pm \mathrm{SD})\end{array}$ & $0.028^{*}$ \\
\hline $\begin{array}{l}\text { VDR mRNA level } \\
(\text { mean } \pm \text { SD })\end{array}$ & $3.9 \pm 0.5$ & 2. $8 \pm 0.7$ & $2.0 \pm 0.61$ & $1.7 \pm 0.8$ & $0.031^{*}$ & $0.042^{*}$ \\
\hline
\end{tabular}

VDR; vitamin D receptor Adjusted OR: multivariate analysis; OR adjusted for age, family history, exercise, back injury and heavy physical load. *Significant $(\mathrm{P}<0.05)$.

\subsection{Relation of Vitamin D Receptor Fok1 Gene Polymorphism, Expression and Vitamin D Levels with the Grade of Disc Degeneration in LDD Patients}

There were no significant differences of VDR Fok1 genotypes and alleles' frequencies between the different grades of disc degeneration in LDD group. Furthermore, no significant association was found between VDR mRNA and vitamin $\mathrm{D}$ levels and the grade of disc degeneration in LDD group (adjusted $\mathrm{P}=0.25$ and adjusted $\mathrm{P}=0$ ) respectively (Table 4 ).

\subsection{Relation of Vitamin D Receptor Fok1 Gene Polymorphism, Expression and Vitamin D Levels with Disc Herniation in LDD Patients}

VDR Fok1 Ff, ff genotypes and $\mathrm{f}$ allele were significantly increased the risk of herniation in LDD patients (adjusted $\mathrm{OR}=2.3,95 \% \mathrm{CI}=1.43-4.77$ and $\mathrm{P}=$ 0.037 , adjusted $\mathrm{OR}=4.2,95 \% \mathrm{CI}=1.93-9.8$ and $\mathrm{P}=0.04$ and adjusted $\mathrm{OR}=$ $2.8,95 \% \mathrm{CI}=1.6-3.82$ and $\mathrm{P}=0.021)$ respectively. Also, VDR mRNA and vitamin D levels was significantly decreased with the occurrence of disc herniation in LDD patients (adjusted $\mathrm{P}=0.038$ and adjusted $\mathrm{P}=0.03$ ) respectively (Table $5)$. 
Table 4. VDR Fok1 gene polymorphism, expression and vitamin D levels as regards the grade of disc degeneration in LDD patients.

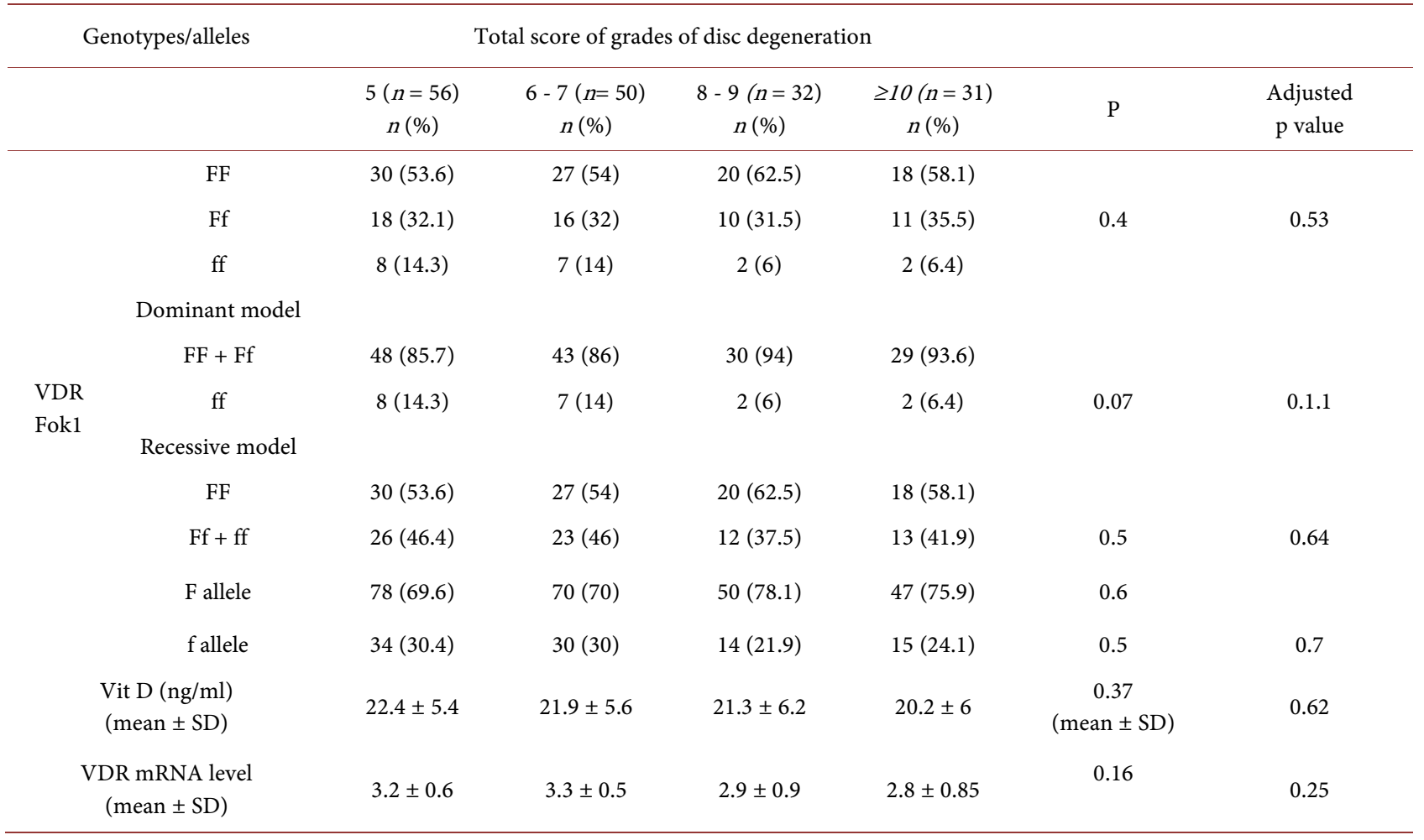

VDR; vitamin D receptor Adjusted OR: multivariate analysis; OR adjusted for age, family history, exercise, back injury and heavy physical load. ${ }^{*}$ Significant $(\mathrm{P}<0.05)$

Table 5. VDR Fok1 gene polymorphism, expression and vitamin D levels as regards disc herniation in LDD patients.

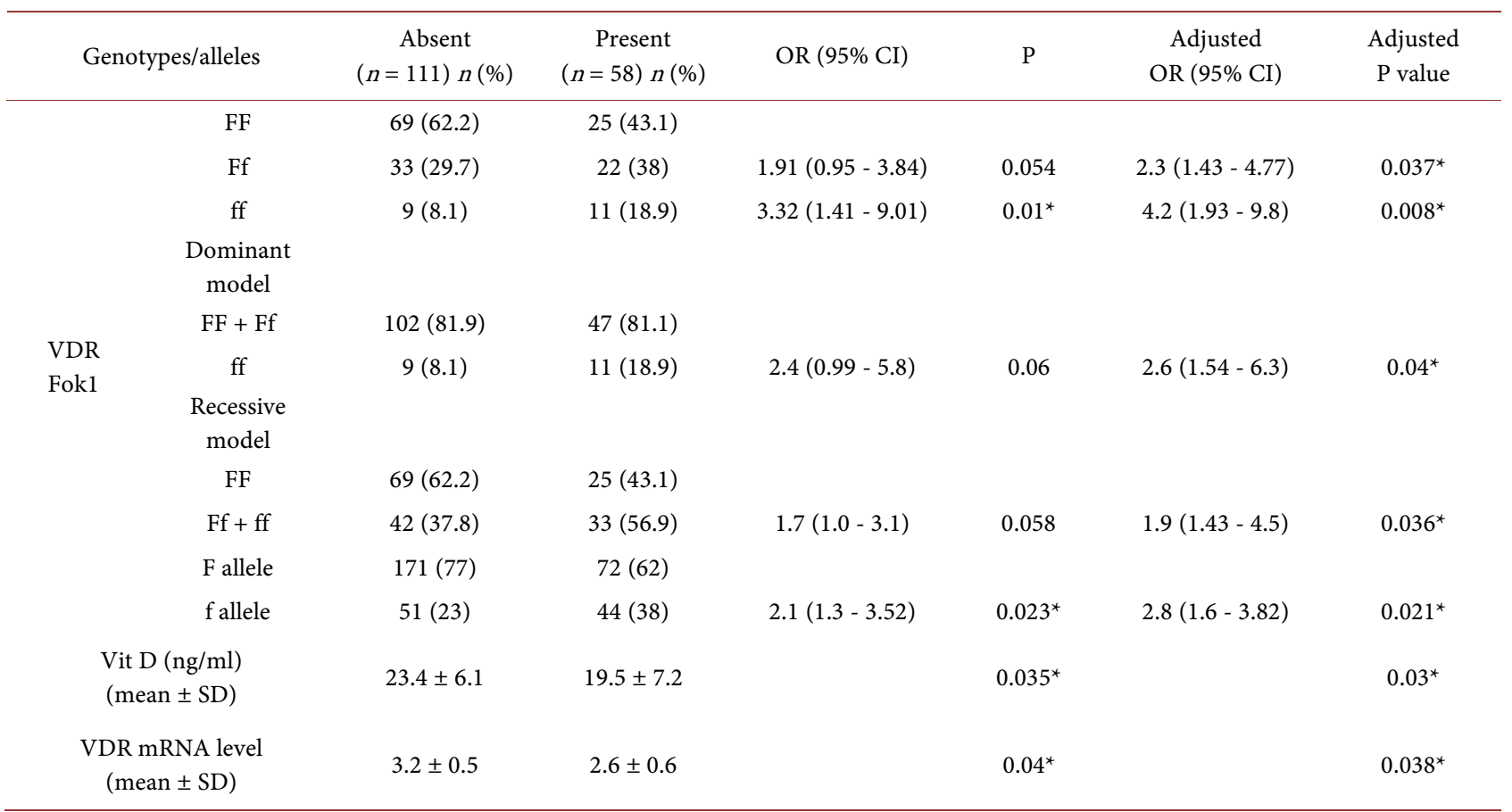

VDR; vitamin D receptor Adjusted OR: multivariate analysis; OR adjusted for age, family history, exercise, back injury and heavy physical load $\star_{\text {Significant }}$ $(\mathrm{P}<0.05)$ 


\subsection{Effect of VDR Gene Fok1 Polymorphism on VDR mRNA Expression in the Studied Groups}

VDR mRNA expression level was significantly decreased in VDR Fok1 ff genotype carriers' compared to FF genotype $(\mathrm{P}<0.01)$ in both the controls and LDD patients, while, there was no significant difference of VDR mRNA expression level between VDR Fok1 Ff and FF genotype or ff genotype (Table 6).

\subsection{Correlation between Vitamin D Level and VDR mRNA Expression in Patients with LDD}

We observed a positive correlation between vitamin D level and VDR mRNA expression in patients with $\operatorname{LDD}(\mathrm{r}=0.7, \mathrm{p}<0.001)$.

\section{Discussion}

LDD became a very complex condition in the last decades, where genetic factors had a central role. So to be there is a lot to understand about the development of degenerative disc disease [24].

In our study, there was a significant difference concerning age, family history, back injury, exercise and heavy physical load on comparing LDD patients to control group and all considered to be triggering agents in the pathogenesis of LDD together with other factors impairing disc nutrition [25]. Ever since the end of the 20th century, many have suggested that genetics is responsible mainly for the evolution of LDD and that environmental factors exert a much smaller role than formerly supposed [26].

Our study may be the first work that measured and showed an association of VDR FokI variable, the expression of VDR mRNA and the levels of vitamin D with the risk, grade and number of levels of lumber disc degeneration and herniation in the Egyptian population.

The work was done on female subjects to boot out any gender-linked association of VDR-FokI polymorphism and risk of LDD as proved by Colombini et al., 2015 [27].

We establish a solid association between VDR ff genotype, $f$ allele and the occurrence of LDD in Egyptians, also the subjects with ff genotype were significantly more likely to have the multilevel disc degeneration with increased risk of disc herniation. Furthermore, VDR mRNA expression was significantly decreased

Table 6. Effect of VDR gene Fok1 polymorphism on VDR mRNA expression in the studied groups.

\begin{tabular}{ccccccc}
\hline & \multicolumn{3}{c}{ Control group $(\mathrm{N}=169)$} & \multicolumn{3}{c}{ LDD group (N=169) } \\
\hline Genotypes (n) & $\begin{array}{c}\text { FF } \\
(n=121)\end{array}$ & $\begin{array}{c}\text { Ff } \\
(n=45)\end{array}$ & $\begin{array}{c}\text { ff } \\
(n=3)\end{array}$ & $\begin{array}{c}\text { FF } \\
(n=95)\end{array}$ & $\begin{array}{c}\text { Ff } \\
(n=55)\end{array}$ & $\begin{array}{c}\text { ff } \\
(n=19)\end{array}$ \\
$\begin{array}{c}\text { VDR mRNA } \\
\text { expression } \\
(\text { mean } \pm \text { SD })\end{array}$ & $4.01 \pm 0.5$ & $3.9 \pm 0.8$ & $3.2 \pm 0.71^{*}$ & $3.1 \pm 0.7$ & $2.88 \pm 0.9$ & $2.5 \pm 0.75^{*}$ \\
\hline
\end{tabular}

${ }^{*} \mathrm{P}<0.05$ when compared to FF genotype. 
in LDD group compared to control group and this decreased expression was significantly associated with multilevel disc degeneration and increased risk of hernia. Likewise, the VDR mRNA expression level was significantly decreased in VDR Fok1 ff genotype compared to FF genotype [P $<0.01]$. This accords with previous studies done on Turkish [14] and Brazilian subjects [28] [29]. On the contrary, other studies found no association between FokI genotypes and disc pathologies as in an Italian study [30], a Norway case/control study [31] and in Mexican Mestizo Patients [32]. Fok1 [rs2228570] is a polymorphism [ATG to ACG] toward the start of two potential translation initiation sites in exon 2 of VDR. People with $\mathrm{T}$ allele, the risk allele [designated $\mathrm{f}$ ], start translation of the first start site, delivering a full-length VDR protein [33]. Those with the $\mathrm{C}$ allele [designated F] start translation at the second start site, and deliver a shorter protein. Be that as it may, the $\mathrm{F}$ allele [shorter allele] collaborates all more effectively with the transcription factor and shows generally expanded capacity contrasted with the $\mathrm{f}$ allele [longer allele] [33]. Videman et al. [1989] [9] found that in a study of 170 men, those with a ff genotype had the signal power $9.3 \%$ lower and an outline degeneration score $6.9 \%$ more risky than men with the FF genotype. It is said that the longer $f$ allele, which seems to bring about diminished VDR capacity, expands the threat of degeneracy. The definite mechanism of diminished VDR capacity, prompting degeneration is not surely known. It was recommended that vitamin D may balance sulfate concentrations and decide the level of proteoglycans [PG] sulfation, which is basic for disc stability [34].

The $\mathrm{f}$ allele, with diminished VDR capacity, may add to not exactly ideal disc structure that is inclined to early degeneration. An observational study distinguished the presence of VDR in the chondrocyte nucleoli, particularly in the fibrillar part, indicating that vitamin $\mathrm{D}$ had a very important role in the differentiation, proliferation, and maturation of cartilage cells. Kawaguchi et al. [2002] [35] proposed that this polymorphism in the vitamin $\mathrm{D}$ receptor gene might modify the morphological features of the matrix in the intervertebral disc. Fok1 polymorphism is considered as an independent polymorphism and straightforwardly connected with pathological conditions; the linkage disequilibrium [LD] territory encompassing this polymorphism is by all accounts little [36]. The differences between these outcomes might be because of the distinction of the specimen size or contrasts in the ethnic inceptions of the patients.

This work was one of the rare studies which detected the level of vitamin D in LDD patients; we established that vitamin D levels were significantly diminished in the LDD group of patients compared to the controls. It also decreased in the numbers of levels of disc degeneration and the risk of disc herniation. We observed a positive correlation between concentrations of vitamin D level and VDR mRNA expression in patients with LDD.

Few studies assessed the level of vitamin $\mathrm{D}$ in disc degeneration; one of them demonstrated that vitamin $\mathrm{D}$ deficiency was connected up with cervical disc herniation in a populace of grown-ups experiencing spine surgery [37]; another recognized low vitamin D level in patients of chronic low back pain [38]. The 
harmony disc nutrition and disc excretion of waste products are an essential variable which may prompt disc degeneration [39]. Vitamin D has immune regulatory capacities which can down manage proinflammatory cytokines and upregulate mitigating cytokines. Many specialists reported the part of inflammatory cytokines in the pathogenesis of LDD. The herniated core pulposus, either with immunogenic properties itself or by instigating an immunologic reaction in the nerve roots, dorsal root ganglia and encompassing muscles, is the beginning stage for the course of inflammation started through immune cell activation, infiltration and cytokine discharge [40].

We declare some limitations. First, small size of the sample: as a larger study size would probably provide an even strong statistical power; therefore, further studies with increased numbers of patients are required to validate our findings

The second limitation was the difference in age between the control group and the patients with disc disease. This may potentially affect the relative exposure of the 2 groups to sunned ultraviolet beam which affects $25(\mathrm{OH})$ D levels. However, with careful history taking from the participant, they nearly have the same characteristics of sun exposure in the governorate.

\section{Competing Interests}

The authors declare that they have no competing interests.

\section{Availability of Data and Materials}

The data supporting the conclusions of this article are available at the corresponding author as it cannot be available in any format online due to privacy issue. However, researchers who need to get access to these data can contact the corresponding author.

\section{Ethical Approval}

The study protocol was approved by the ethical committee of Faculty of Medicine, Zagazig University.

\section{Authors' Contributions}

Sabbah N. carried out the following tasks: Conception and design, molecular genetic studies and techniques (PCR, Gene expression, HPLC), collection and assembly of data, analysis and interpretation of the data, statistical processing of the data, drafting of the article, final approval of the article.

Rezk N. performed the following: Conception and design, molecular genetic studies and techniques (PCR, Gene expression, HPLC), collection and assembly of data, analysis and interpretation of the data, statistical processing of the data, drafting of the article, publication of the article.

Taha M. shared in conception and design, funding of the article, administrative, technical, and logistic support, provision of patients, collection and assembly of data, critical revision of the article for important intellectual content, final approval of the article. 
Mansour H. shared in technical support, funding, and final approval of the article.

\section{Acknowledgements}

We would like to thank all members of both medical biochemistry and neurosurgery department for facilitating the performance of this work.

\section{References}

[1] Juniper, M., Le, T.K. and Mladsi, D. (2009) The Epidemiology, Economic Burden, and Pharmacological Treatment of Chronic Low Back Pain in France, Germany, Italy, Spain and the UK: A Literature-Based Review. Expert Opinion on Pharmacotherapy, 10, 2581-2592. https://doi.org/10.1517/14656560903304063

[2] Cheung, K.M., Karppinen, J., Chan, D., et al. (2009) Prevalence and Pattern of Lumbar Magnetic Resonance Imaging Changes in a Population Study of One Thousand Forty-Three Individuals. Spine, 34, 934-940. https://doi.org/10.1097/BRS.0b013e3181a01b3f

[3] Zhang, Y.G., Sun, Z., Zhang, Z., Liu, J. and Guo, X. (2009) Risk Factors for Lumbar Intervertebral Disc Herniation in Chinese Population: A Case-Control Study. Spine, 34, E918-E922. https://doi.org/10.1097/BRS.0b013e3181a3c2de

[4] Zawilla, N.H., Darweesh, H., Mansour, N., et al. (2014) Matrix Metalloproteinase-3, Vitamin D Receptor Gene Polymorphisms, and Occupational Risk Factors in Lumbar Disc Degeneration. Journal of Occupational Rehabilitation, 24, 370-381. https://doi.org/10.1007/s10926-013-9472-7

[5] Kalichman, L. and Hunter, D.J. (2008) The Genetics of Intervertebral Disc Degeneration. Associated Genes. Joint Bone Spine, 75, 388-396.

https://doi.org/10.1016/j.jbspin.2007.11.002

[6] Walter, B.A., Korecki, C.L., Purmessur, D., Roughley, P.J., Michalek, A.J. and Iatridis, J.C. (2011) Complex Loading Affects Intervertebral Disc Mechanics and Biology. Osteoarthritis and Cartilage, 19, 1011-1018. https://doi.org/10.1016/j.joca.2011.04.005

[7] Battie, M.C., Videman, T., Levalahti, E., Gill, K. and Kaprio, J. (2007) Heritability of Low Back Pain and the Role of Disc Degeneration. Pain, 131, 272-280. https://doi.org/10.1016/j.pain.2007.01.010

[8] Cantorna, M.T. and Mahon, B.D. (2004) Mounting Evidence for Vitamin D as an Environmental Factor Affecting Autoimmune Disease Prevalence. Experimental Biology and Medicine, 229, 1136-1142.

[9] Videman, T., Leppävuori, J., Kaprio, J., Battie, M.C., Gibbons, L.E., et al. (1998) Intragenic Polymorphisms of the Vitamin D Receptor Gene Associated with Intervertebral Disc Degeneration. Spine, 23, 2477-2485. https://doi.org/10.1097/00007632-199812010-00002

[10] Uitterlinden, A.G., Fang, Y., van Meurs, J.B.J., Pols, H.A.P. and van Leeuwen, J.P.T.M. (2004) Genetics and Biology of Vitamin D Receptor Polymorphisms. Gene, 338, 143-156.

[11] Carlberg, C. and Molnar, F. (2006) Detailed Molecular Understanding of Agonistic and Antagonistic Vitamin D Receptor Ligands. Current Topics in Medicinal Chemistry, 6, 1243-1253. https://doi.org/10.2174/156802606777864908

[12] Mory, D.B., Rocco, E.R., Miranda, W.L., et al. (2009) Prevalence of Vitamin D Receptor Gene Polymorphisms FokI and BsmI in Brazilian Individuals with Type 1 
Diabetes and Their Relation to Beta-Cell Autoimmunity and to Remaining BetaCell Function. Human Immunology, 70, 447-451. https://doi.org/10.1016/j.humimm.2009.03.007

[13] Vilarino, F.L., Bianco, B., Christofolini, D.M., et al. (2011) Analysis of VDR Gene Polymorphism Fok1 in Infertile Women with Endometriosis. Revista Brasileira de Ginecologia e Obstetrícia, 33, 65-69.

[14] Eser, B., Cora, T., Eser, O., Kalkan, E., Haktanir, A., et al. (2010) Association of the Polymorphisms of Vitamin D Receptor and Aggrecan Genes with Degenerative Disc Disease. Genetic Testing and Molecular Biomarkers, 14, 313-317. https://doi.org/10.1089/gtmb.2009.0202

[15] Eskola, P.J., Kjaer, P., Daavittila, I.M., Solovieva, S., Okuloff, A., et al. (2010) Genetic Risk Factors of Disc Degeneration among 12 - 14-Year-Old Danish Children: A Population Study. International Journal of Molecular Epidemiology and Genetics, 1 , 158-165.

[16] Kelempisioti, A., Eskola, P.J., Okuloff, A., Karjalainen, U., Takatalo, J., et al. (2011) Genetic Susceptibility of Intervertebral Disc Degeneration among Young Finnish Adults. BMC Medical Genetics, 12, 153. https://doi.org/10.1186/1471-2350-12-153

[17] Wiktorin, C., Hjelm, E.W., Winkel, J. and Köster, M. (1996) Reproducibility of a Questionnaire for Assessment of Physical Load during Work and Leisure Time. Journal of Occupational \& Environmental Medicine, 38, 190-201. https://doi.org/10.1097/00043764-199602000-00017

[18] Schneiderman, G., Flannigan, B., Kingston, S., Thomas, J., Dillin, W.H. and Watkins, R.G. (1987) Magnetic Resonance Imaging in the Diagnosis of Disc Degeneration: Correlation with Discography. Spine, 12, 276-281. https://doi.org/10.1097/00007632-198704000-00016

[19] Horst-Sikorska, W., Kalak, R., Wawrzyniak, A., et al. (2007) Association Analysis of the Polymorphisms of the VDR Gene with Bone Mineral Density and the Occurrence of Fractures. Journal of Bone and Mineral Metabolism, 25, 310-319. https://doi.org/10.1007/s00774-007-0769-5

[20] Cross, H.S., Bareis, P., Hofer, H., Bischof, M.G., Bajna, E., Kriwanek, S., Bonner, E. and Peterlik, M. (2001) 25-Hydroxyvitamin D[3]-1Alpha-Hydroxylase and Vitamin D Receptor Gene Expression in Human Colonic Mucosa Is Elevated during Early Cancerogenesis. Steroids, 66, 287-292.

[21] Ursula, T., Ulla, H. and Ulf-Håkan, S. (2003) Determination of 25-Hydroxyvitamin D in Serum by HPLC and Immunoassay. Clinical Chemistry, 49, 1521-1524. https://doi.org/10.1373/49.9.1521

[22] Gilbertson, T.J. and Stryd, R.P. (1997) High-Performance Liquid Chromatographic Assay for 25-Hydroxyvitamin D3 in Plasma. Clinical Chemistry, 23, 1700-1704.

[23] Skol, A.D., Scott, L.J., Abecasis, G.R. and Boehnke, M. (2006) Joint Analysis Is More Efficient than Replication-Based Analysis for Two-Stage Genome-Wide Association Studies. Nature Genetics, 38, 209-213. https://doi.org/10.1038/ng0306-390

[24] Chan, W.C.W., Sze, K.L., Samartzis, D., Leung, V.Y.L. and Chan, D. (2011) Structure and Biology of the Intervertebral Disc in Health and Disease. Orthopedic Clinics of North America, 42, 447-464. https://doi.org/10.1016/j.ocl.2011.07.012

[25] Samartzis, D., Karppinen, J., Mok, F., Fong, D.Y.T., Luk, K.D.K., et al. (2011) A Population-Based Study of Juvenile Disc Degeneration and Its Association with Overweight and Obesity, Low Back Pain, and Diminished Functional Status. Journal of Bone \& Joint Surgery-American Volume, 93, 662-670. https://doi.org/10.2106/JBJS.I.01568

[26] Matsui, H., Terahata, N., Tsuji, H., Hirano, N. and Naruse, Y. (1992) Familial Pre- 
disposition and Clustering for Juvenile Lumbar Disc Herniation. Spine, 17, 1323 1328. https://doi.org/10.1097/00007632-199211000-00011

[27] Colombini, A., Brayda-Bruno, M., Ferino, L., Lombardi, G., Maione, V., Banfi, G. and Cauci, S. (2015) Gender Differences in the VDR-FokI Polymorphism and Conventional Non-Genetic Risk Factors in Association with Lumbar Spine Pathologies in an Italian Case-Control Study. International Journal of Molecular Sciences, 16, 3722-3739. https://doi.org/10.3390/ijms16023722

[28] Vieira, L., De Marchi, P., Santos, A., Christofolini, D., Barbosa, C., Fonseca, F., Bianco, B. and Rodrigues, L. (2014) Analysis of FokI Polymorphism of Vitamin D Receptor Gene in Intervertebral Disc Degeneration. Genetic Testing and Molecular Biomarkers, 18, 625-629.

[29] Nunes, F.T.B., Conforti-Froes, N.D.T., Negrelli, W.F. and Sousa, D.R.S. (2007) Genetic and Environmental Factors Involved on Intervertebral Disc Degeneration. Acta Ortopédica Brasileira, 15, 9-13. https://doi.org/10.1590/S1413-78522007000100002

[30] Colombini, A., Brayda-Bruno, M., Lombardi, G., Croiset, S.J., Vrech, V., et al. (2014) FokI Polymorphism in the Vitamin D Receptor Gene [VDR] and Its Association with Lumbar Spine Pathologies in the Italian Population: A Case-Control Study. PLoS ONE, 9, e97027. https://doi.org/10.1371/journal.pone.0097027

[31] Omair, A., Lie, B.A., Reikeras, O. and Brox, J.I. (2012) An Association Study of Interleukin 18 Receptor Genes [IL18R1 and IL18RAP] in Lumbar Disc Degeneration. The Open Orthopaedics Journal 6, 164-171. https://doi.org/10.2174/1874325001206010164

[32] Serrano, S.C., Villareal, D.G., Aguilar-Medina, M., et al. (2014) Genetic Polymorphisms of Interleukin-1 Alpha and the Vitamin D Receptor in Mexican Mestizo Patients with Intervertebral Disc Degeneration. International Journal of Genomics, 2014, Article ID: 302568.

[33] Arai, H., Miyamoto, K., Taketani, Y., et al. (1997) A Vitamin D Receptor Gene Polymorphism in the Translation Initiation Codon: Effect on Protein Activity and Relation to Bone Mineral Density in Japanese Women. Journal of Bone and Mineral Research, 12, 915-921. https://doi.org/10.1359/jbmr.1997.12.6.915

[34] Corvol, M.T., Dumontier, M.F., Tsagris, L., Lang, F. and Bourguignon, J. (1981) Cartilage and Vitamin D in Vitro [author's transl]. Annales d Endocrinologie, 42, 482-487.

[35] Kawaguchi, Y., Kanamori, M., Ishihara, H., Ohmori, K., Matsui, H. and Kimura, T. (2002) The Association of Lumbar Disc Disease with Vitamin-D Receptor Gene Polymorphism. Journal of Bone \& Joint Surgery-American Volume, 84, 2022-2028. https://doi.org/10.2106/00004623-200211000-00018

[36] Nejentsev, S., Godfrey, L., Snook, H., et al. (2004) Comparative High-Resolution Analysis of Linkage Disequilibrium and Tag Single Nucleotide Polymorphisms between Populations in the Vitamin D Receptor Gene. Human Molecular Genetics, 13, 1633-1639. https://doi.org/10.1093/hmg/ddh169

[37] Stoker, G., Buchowski, J., Chen, C., Kim, H., Park, M.S. and Riew, K.D. (2013) Hypovitaminosis D and Cervical Disk Herniation among Adults Undergoing Spine Surgery. Global Spine Journal, 3, 231-236. https://doi.org/10.1055/s-0033-1354252

[38] Lodh, M., Goswami, B., Mahajan, R.D., Sen, D., Jajodia, N. and Roy, A. (2015) Assessment of Vitamin D Status In Patients of Chronic Low Back Pain of Unknown Etiology. Indian Journal of Clinical Biochemistry, 30, 174-179. https://doi.org/10.1007/s12291-014-0435-3

[39] Shankar, H., Scarlett, J.A. and Abram, S.E. (2009) Anatomy and Pathophysiology of 
Intervertebral Disc Disease. Techniques in Regional Anesthesia \& Pain Management, 13, 67-75. https://doi.org/10.1053/j.trap.2009.05.001

[40] Shamji, M.F., Setton, L.A., Jarvis, W., So, S., Chen, J., Jing, L., Bullock, R., Isaacs, R.E., Brown, C. and Richardson, W.J. (2010) Proinflammatory Cytokine Expression Profile in Degenerated and Herniated Human Intervertebral Disc Tissues. Arthritis \& Rheumatology, 62, 1974-1982.

Submit or recommend next manuscript to SCIRP and we will provide best service for you:

Accepting pre-submission inquiries through Email, Facebook, LinkedIn, Twitter, etc. A wide selection of journals (inclusive of 9 subjects, more than 200 journals)

Providing 24-hour high-quality service

User-friendly online submission system

Fair and swift peer-review system

Efficient typesetting and proofreading procedure

Display of the result of downloads and visits, as well as the number of cited articles Maximum dissemination of your research work

Submit your manuscript at: http://papersubmission.scirp.org/

Or contact ojmn@scirp.org 